camera Iucida drawing shows the distribution of phosphatase-positive and -negative substances, the former shown as black. In preparations stained by the ordinary histological methods, these tissues did not differ from each other and both of them were composed of typical chromaffin medullary cells.

The influence on the adrenal medulla of procedures stimulating medullary secretion was examined; for example, adrenals of rats killed during prolonged severe insulin shock were compared with those of normal controls. No certain qualitative differences could be seen. Therefore, areas of phosphatasepositive and -negative tissues were measured planimetrically in sections cut serially. These quantitative studies revealed a statistically significant increase in the volume of the phosphatase-negative tissues of the animals treated with insulin. The volumes of the phosphatase-positive tissues were approximately equal in both groups.

The presence of two kinds of medullary tissues can also be demonstrated with other histochemical techniques ${ }^{3}$. The phosphatase-negative islets are selectively darkened by a short immersion in ammoniacal silver nitrate and they fluoresce brilliantly in ultra-violet light. The significance of the two types of islets is not clear; but both of them have hitherto been seen only in species the adrenals of which contain both noradrenaline and adrenaline.

Further work is in progress.

Department of Anatomy,

O. ERÄNKÖ

University of Helsinki. Jan. 22.

1 Erănkö, o., Ann. med. exper. et biol. Fennice (in the press).

: Gomori, G., Arch. Path., 32, 189 (1941).

'Eränkö, O. (to:be published).

\section{Methylation of a Phenolic Hydroxyl Group in the Human Body}

Is the course of clinical trials of the antithyroxine compound, $n$-butyl 3:5-diiodo-4-hydroxybenzoate ${ }^{1}$, on patients with thyrotoxicosis, the nature of the substances excreted in the urine was investigated. Practically the whole of the urinary iodine $(545 \mathrm{mgm}$. per diem) was accounted for by the presence of a mixture of 3:5-diiodo-4-hydroxy-and, somewhat surprisingly, $3: 5$-diiodo-4-methoxy-benzoic acids in approximately equal proportions.

The acidified urine was extracted with ether, and the ether layer further extracted with sodium hydroxide. Acidification of the alkaline solution precipitated a mixture of iodinated benzoic acids, which, after crystallization from alcohol, melted at $247^{\circ}$ (decomp.). This is rather higher than the figure in the literature ${ }^{2}$, namely, $237^{\circ}$, for $3: 5$-diiodo-4hydroxybenzoic acid. The analytical figures (C, 24.4 ; $\mathrm{H}, \mathrm{I} \cdot 6$; I, $62 \cdot 2$ per cent), however, approximated more closely to those for 3:5-diiodo-4-methoxybenzoic acid (calc. for $\mathrm{C}_{8} \mathrm{H}_{6} \mathrm{Q}_{3} \mathrm{I}_{2}: \mathrm{C}, 23.7 ; \mathrm{H}, 1.5$; I, $62 \cdot 8$ per cent) than to those for the hydroxy-acid (calc. for $\mathrm{C}_{7} \mathrm{H}_{4} \mathrm{O}_{3} \mathrm{I}_{2}$ : C, $2 \mathrm{l} \cdot 5 ; \mathrm{H}, 1 \cdot 0 ; \mathrm{I}, 65 \cdot 2$ per cent). Repeated recrystallization finally raised the melting point to $261^{\circ}$ (decomp.). Wheeler and Liddle ${ }^{3}$ report that the methoxy-acid decomposes at 255$256^{\circ}$.

Esterification of the mixed acids with methanol and sulphuric acid gave a mixture of the methyl hydroxy-and methoxy-esters, which were separated by virtue of the solubility of the former in alkali.
The methyl $3: 5$-diiodo-4-hydroxybenzoate crystallized from methanol in colourless needles, melting point $168^{\circ}$ (in the literatur $\theta^{3}, 166-167^{\circ}$ ) (found : C, $24.2 ; \mathrm{H}, 1.6$; $\mathrm{I}, 62 \cdot 7$; calc. for $\mathrm{C}_{8} \mathrm{H}_{6} \mathrm{O}_{3} \mathrm{I}_{2}$ : $\mathrm{C}, 23 \cdot 7 ; \mathrm{H}, 1.5 ; \mathrm{I}, 62 \cdot 8$ per cent). A mixed melting point with an authentic sample produced no depression. The methyl 3 : 5-diiodo-4-methoxybenzoate, crystallized similarly, had melting point $95^{\circ}$ (in the literature ${ }^{3}, 95^{\circ}$ ) (found : C, 26.1; $\mathrm{H}, 1.9$; I, 60.6 ; calc. for $\mathrm{C}_{8} \mathrm{H}_{8} \mathrm{O}_{3} \mathrm{I}_{2}$ : $\mathrm{C}, 25 \cdot 85 ; \mathrm{H}, 1.9 ; \mathrm{I}, 60.8$ per cent). Admixture with an authentic specimen did not depress the melting point.

This work will be discussed more fully elsewhere; but in view of the absence of references in the literature to the methylation of phenolic hydroxyl groups in the animal body (see Lederer ${ }^{4}$ ), we considered it desirable to place these preliminary results on record.

N. F. Maclagan

J. H. WILKINSON

Department of Chemical Pathology,

Westminster Medical School,

(University of London), London, S.W.I.

March 30.

${ }^{1}$ Sheahan, M. M., Wilkinson, J. H., and Maclagan, N. F., Biochem. $J ., 48,188$ (1951).

Paal, C., and Mohr, L., Ber., 28, 2302 (1896).

Wheeler, H. L., and Liddle, L. M., Amer. Chem. J., 42, 441 (1910)

- Lederer, E., J. Chem. Soc., 2120 (1949).

\section{Combination of Nitrogen-I5-labelled Nitrogen Mustard with Proteins}

THE nitrogen mustards readily inactivate certain enzymes ${ }^{1}$ and they also react with many other proteins ${ }^{2}$, including the components of hæmolytic complement ${ }^{3}$. Although it has been established by various investigators that the amino, sulphydryl, sulphide, carboxyl and pyridine groups of proteins are affected by the action of the nitrogen mustards ${ }^{4}$, there appears to be no precise quantitative information about the combination of the mustard with proteins.

We have recently prepared one of the most commonly used nitrogen mustards, methyl bis ( $\beta$-chloroethyl)amine (code No. HN2), labelled with nitrogen15, and have used this tagged compound (containing 30.4 atoms per cent excess nitrogen-15) to determine the amount of nitrogen mustard which combines firmly with various proteins at $p H \mathrm{H} 7 \cdot 4$ and $37^{\circ}$.<smiles>CN(CCCl)CCCl</smiles>

Methyl bis( $\beta$-chloroethy)lamine

Our investigations have shown that considerable amounts of this nitrogen mustard combine firmly with the serum proteins and ovalbumin. The compounds produced contain appreciable amounts of nitrogen-15 even after prolonged dialysis, or precipitation followed by repeated washing with methanol, to remove loosely attached nitrogen mustard and its 'hydrolysis' products (cyclic and other transformation compounds formed by the nitrogen mustards in aqueous solution). The following results of typical experiments with ovalbumin show that the protein treated with nitrogen mustard may contain $\mathbf{3 . 5}$ 